\title{
25 lat działalności Odrodzonego Rycerskiego Zakonu Bibliofilskiego z Kapitułą Orderu Białego Kruka w Krakowie
}

Jedyny na świecie Rycerski Zakon Bibliofilski z Kapitułą Orderu Białego Kruka powstał 13 lutego 1930 r. z inicjatywy prof. Kazimierza Witkiewicza, zwanego „Polskim Michałem Aniołem", oraz wybitnych bibliofilów krakowskich współpracujących w utworzonym w 1923 r. Towarzystwie Miłośników Książki. Zakon działa według własnej konstytucji, najkrótszej na świecie, bowiem składającej się z pięciu artykułów, z których najważniejszy stanowi, iż „Najwyższą cnotą zakonu jest miłość do ksiąg”. Ma także określoną strukturę, tytulaturę ${ }^{1}$ Dostojnych Braci, insygnia, emblemat, hymn oraz rytuał „zmyszeń”, jak nazywają się zakonne spotkania. Nazwa powstała od symbolu białej myszki bibliofilskiej przejętej z Towarzystwa Miłośników Książki. Miejscami spotkań krakowskich bibliofilów były: gabinet kustosza biblioteki Miejskiego Muzeum Przemysłowego, późniejszego wicedyrektora Muzeum Przemysłowego, Kazimierza Witkiewicza, także „Stolik Bibliofilski” w najsłynniejszym krakowskim „Hotelu Grand” przy ul. Sławkowskiej 5/7, a po II wojnie światowej „Gniazdo Białego Kruka”, to znaczy mieszkanie Witkiewiczów w budynku Akademii Sztuk Pięknych w Krakowie przy ul. Smoleńsk 9/2. Wspaniałe lata ,pięknej Polaków zabawy" zapisywały się złotymi zgłoskami nie tylko w Krakowie i w Polsce. W świat szły informacje o niezwykłym Zakonie, jego działalności, w tym o nadawaniu Orderu Białego Kruka wybitnym bibliofilom, m.in. Louis Barthou (1862-1934), ministrowi spraw zagranicznych Francji w rządzie Gastona Doumergue'a i Stanisławowi Wojciechowi Okoniewskiemu (1870-1944), biskupowi chełmskiemu od 1925 r. z Pelplina. Działalności Zakonu nie przerwała nawet II wojna światowa, a czas powojenny słynął z przypominania Polakom i Europie o jego istnieniu dzięki niestrudzonej działalności założyciela i Wielkiego Mistrza Zakonu Kazimierza Witkiewicza, który kontynuował dzieło wyróżniania wybitnych miłośników ksiąg z kraju i z zagranicy orderami Białego Kruka. Wśród nich byli np. Samuel Tyszkiewicz, słynny drukarz z Florencji (Order nadany pośmiertnie w 1956), Igor Bełza z Moskwy (1961), Alfred Holender-Holiński z Londynu (1959). Względy polityczne sprawiły jednak, że decyzją Wielkiego Mistrza Kazimierza, potwierdzoną podpisami dwóch Braci, Zakon został w 1963 r. ,zakryty”, jak zapisano w stosownym piśmie.

Po śmierci Kazimierza (21 października 1973), Jego Syn Tadeusz Eugeniusz Witkiewicz kontynuował bibliofilskie spotkania, które przyjęły nazwę zaproponowaną przez red.

${ }^{1}$ W Konstytucji Zakonu z 1930 r. zapisano następujące godności: Wielki Komandor Wschodu, Wielki Mistrz Zakonu, Kanclerz, Pieczętarz, Jałmużnik, Orator, Kantor, Kapitałka. Od 1992 r. w Odrodzonym Zakonie pozostawiono godności, dodając do nich tytuły: Typografa, Dziejopisa i Dostojnej Makulatury, a także wprowadzono godność Dama Książki zamiast Kapitałki. W Supplementum do Ustawy Konstytucyjnej wprowadzonym w 2015 r. dodano kolejne godności związane ze specjalizacją: Miniaturzysta, Bibliograf, Kustosz, Archiekslibrisofil. Przywrócono również godność Kapitałka z zachowaniem godności Dama Książki. W uznaniu zasług dla Książki, bibliofilstwa i Zakonu przyznawany jest Patent ze Złoceniami. 
Ewę Zagórską „Imieniny Książki”, a odbywają się w marcu². Również od tamtego czasu, bibliofile krakowscy zbierali się co roku w rocznicę śmierci Kazimierza Witkiewicza w Bazylice Ojców Franciszkanów na mszy św. odprawianej za Jego duszę, a później także za zmarłych Braci z Zakonu z homilią okolicznościową i hymnem bibliofilskim śpiewanym przez wielce zasłużony dla Zakonu Chór Cecyliański. Bardzo ważną rolę w podtrzymywaniu tradycji bibliofilskich w Gnieździe Białego Kruka spełniała Urszula Waleria Dylska, którą Tadeusz Witkiewicz poślubił w $1975 \mathrm{r}$.

Po osiemnastu latach starań i aktywnej działalności wielu krakowskich bibliofilów Zakon odrodził się jak Feniks z popiołów 27 czerwca 1992 r. Dzięki odnalezieniu zapisu Kazimierza Witkiewicza uchylona została decyzja o zakryciu Zakonu, nastapiło reaktywowanie (odkrycie) Kapituły oraz utworzenie Odrodzonego Rycerskiego Zakonu z Kapitułą Orderu Białego Kruka. Wielkim Mistrzem okrzyknięto Tadeusza Eugeniusza Witkiewicza, syna i spadkobiercę Kazimierza. Nowy Mistrz wspierany był przez żonę Urszulę i krakowskich bibliofilów: prof. Tadeusza Ulewicza, prof. Romana Banaszewskiego, dr med. Adama Maciejasza, doc. dr. hab. Zdzisława Gajdę, mgr. Stanisława Skarbińskiego, red. Tadeusza Zygmunta Bednarskiego, mgr. Kaspra Świerzowskiego.

Odrodzony Rycerski Zakon Bibliofilski w Krakowie, zachowujący witkiewiczowskiego ducha tej konfraterni, przepisy konstytucji z 1930 r., rytuał, hymn bibliofilski oraz ideę, mógł liczyć u progu swojej działalności na medialne wsparcie red. Ewy Owsiany, dzisiaj z tytułem Dama Książki i o znaczących zasługach dla Zakonu, T. Z. Bednarskiego, Mieczysława Kasprzyka i Włodzimierza Jurasza, którzy zamieszczali informacje o Zakonie i jego najnowszych działaniach nie tylko w prasie lokalnej i ogólnopolskiej, ale również polonijnej w USA. Od 1996 r. informacje o Zakonie, również artystycznych i kolekcjonerskich działaniach jego członków, ukazywały się regularnie w czasopiśmie Uniwersytetu Jagiellońskiego „Alma Mater” dzięki Ricie Pagacz-Moczarskiej, redaktor naczelnej. Jej zasługi dla Zakonu zostały potwierdzone nadaniem godności Dama Książki, a następnie uhonorowaniem specjalnym Patentem ze Złoceniami.

Odżyły radosne spotkania bibliofilskie, poszerzał się krąg bibliofilów i miłośników ksiąg propagujących czytelnictwo, upowszechniano ideę przyświecającą Zakonowi oraz jego historię poprzez wystawy (np. w Bibliotece Jagiellońskiej w 1996 i Katedrze Bibliotekoznawstwa Uniwersytetu Jagiellońskiego również w 1996), programy telewizyjne i radiowe oraz publikacje. Nagrania telewizyjne przygotowywane były przez znane redaktorki jak Maria Osterwa-Czekaj, która zrealizowała w 1998 r. program o Rycerskim Zakonie Bibliofilskim z Krakowa w ramach Europejskiego Magazynu Kulturalnego „Alice”, czy Iwona Meus-Jargusz z Krakowskiego Ośrodka Telewizyjnego. Nagrania radiowe zawdzięczamy Marzenie Florkowskiej, obecnie Dama Książki w Zakonie, oraz Katarzynie Pelz. Przedstawiciele konfraterni brali czynny udział w spotkaniach, obchodach, również poza Krakowem, jak chociażby w Pelplinie w 2000 r., gdzie uczestniczono w uroczystościach z okazji 600-lecia urodzin Jana Gutenberga, występując w strojach przynależnych Kanclerzowi i Kapitałce 3 i prowadząc rozmowy z politykami i bibliofilami.

${ }^{2}$ Dla uczczenia pamięci Założyciela i Pierwszego Wielkiego Mistrza, który swe imieniny obchodził w marcu.

${ }^{3}$ Nazwa przyjęta z nazewnictwa introligatorskiego oznaczająca pasek pleciony lub tkany, umieszczony na obu końcach grzbietu dla podtrzymania bloku książki. 
Poszerzano grono Dostojnych Braci Zakonnych, także Dam Książki, jak również wzrastała liczba członków szczycących się mianem Dostojnej Makulatury. Grono to powiększył w 1995 r., ceniony w środowisku bibliofilów księgarz i antykwariusz, kolekcjoner ,tuwimianów” i „,chrzanowianów”, a także dokumentalista - fotograf Edward Edwin Śmiłek. W kolejnych latach zaszczytny tytuł Damy Książki otrzymała w 2002 r. prof. Uniwersytetu Jagiellońskiego Maria Kocójowa, dyrektor Katedry, a potem Instytutu Informacji Naukowej i Bibliotekoznawstwa UJ, która od dawna jest protektorem miłośników ksiąg, entuzjastą Zakonu i promotorką jego działań. W 2004 r. do Zakonu włączony został prof. Tomasz Gryglewicz, połączony więzami rodzinnymi z rodziną Wyrwińskich, z której pochodziła żona Kazimierza Witkiewicza Maria Albertyna. Zakon tym samym pozyskał specjalistę z zakresu historii sztuki, a także ilustracji książkowej.

Z upływem czasu przyszło również żegnać Braci odchodzących w nieodgadnioną krainę Książki. W marcu 1997 r. zmarł Stanisław Skarbiński pełniący funkcję Pieczętarza Zakonu, a 30 lipca 1999 r. Adam Maciejasz, lekarz, poeta, jeden ze współtwórców Odrodzonego Zakonu, w którym piastował funkcję Kanclerza i który wspierał działania konfraterni słowem i sakwa, snując wizje zmian i nowych rozwiązań. Były one jednak zbyt „rewolucyjne” i w istotny sposób zmieniały witkiewiczowską wizję Zakonu, co nie znalazło uznania u Wielkiego Mistrza Tadeusza Witkiewicza. Dla Niego, jego żony Urszuli, Kapitałki, oraz Kanclerza Jerzego Dudy ważniejsze było zachowanie ciagłości tradycji Zakonu. Dlatego wspólne działania koncentrowały się na pracach zmierzających do kontynuowania tradycji radosnego bibliofilstwa wśród naszych konfratrów, na prezentowaniu idei Zakonu wśród szerokiego grona miłośników ksiąg, a także promocji o większym zasięgu idei Zakonu, jego historii i tradycji na forum międzynarodowym. Pierwszą okazją do tego było seminarium w Polskiej Akademii Nauk Stacji Naukowej w Wiedniu, gdzie Jerzy Duda w dniu 5 maja 2001 r. wygłosił referat „Silva Rerum und der Ritterorden der Bibliophilen in Kraków”.

We wrześniu 2001 r. z żalem i smutkiem pożegnaliśmy Wielkiego Mistrza Odrodzonego Zakonu Tadeusza Eugeniusza Witkiewicza. Jemu to poświęciliśmy druczek bibliofilski wydany w $2002 \mathrm{r}$.

Drogą sukcesji Wielkim Mistrzem Odrodzonego Rycerskiego Zakonu Bibliofilskiego w Krakowie został Jerzy Duda, desygnowany przez poprzedniego Wielkiego Mistrza Tadeusza Eugeniusza na kilka lat przed śmiercią. Stosowny patent Wielkiego Mistrza Odrodzonego Zakonu otrzymał z ręki Pieczętarza i Strażniczki „Gniazda Białego Kruka” Urszuli Walerii Witkiewiczowej w czasie uroczystego „zmyszenia” w Gnieździe Białego Kruka w $2001 \mathrm{r}$.

Lata 2005-2007 zapisały się wzrostem liczby różnorodnych promocyjnych działań na rzecz Zakonu, które zapoczątkowane zostały podjęciem współpracy z Domem Kultury „Podgórze” i jego „Galerią ekslibrisu”. Zakon przygotował „zmyszenie” poświęcone bibliotekom oraz wystawę, na której prezentowano małe formy graficzne, to znaczy ekslibrisy, znaki pocztowe i widokówki o tematyce związanej z bibliotekami. W tym okresie włączono do Zakonu, z godnością Dama Książki, prof. Marię Dziedzic z Akademii Sztuk Pięknych w Krakowie, redaktorkę pracy zbiorowej Warsztaty krakowskie 1913-19264 nagrodzonej na 14. Targach Książki w Krakowie w 2010 r. Członkami Zakonu zostali także:

${ }^{4}$ Warsztaty Krakowskie 1913-1926, praca zbiorowa pod red. Marii Dziedzic, Kraków 2010. 
dziennikarka Marzena Florkowska, autorka i współautorka (z mężem) opracowań i książek o niezwykłym kamedule Ojcu Piotrze Rostworowskim, i prof. Zbigniew Majkowski, kierownik Pracowni Projektowania Książki i Typografii ASP w Krakowie, którego uhonorowano godnością Brata Typografa.

W 2006 r. informacje na temat Zakonu pojawiły się w formie elektronicznej na przygotowanej pod odpowiednim hasłem stronie internetowej. Autorką witryny internetowej ${ }^{5}$ jest Dorota Wierzbicka, która napisała również pracę magisterską na ten temat ${ }^{6}$. W 2007 r. Zakon wystapił do Komitetu Obchodów 750. rocznicy lokacji Krakowa z inicjatywą - wspólnie z Muzeum Inżynierii Miejskiej - utworzenia muzeum drukarstwa w zabytkowych obiektach przy ul. św. Wawrzyńca. Inicjatywa i wspólne działania projektowo-organizacyjne z dyrekcją muzeum znalazły swój efektowny finał, to znaczy otwarcia muzeum drukarstwa krakowskiego. Znalazło ono miejsce w wyremontowanym najstarszym budynku zabytkowej zajezdni, w którym umieszczono uratowane od zniszczenia sprzęty, maszyny i urządzenia z zakresu drukarstwa i introligatorstwa.

Zwyczajem stało się zapraszanie artystów malarzy i grafików do przygotowywania ilustracji w drukach zaproszeń na „zmyszenia”. Zaproszenia stały się obiektem kolekcjonerstwa, a to dzięki pozyskiwaniu do współpracy nowych znanych artystów z Ludu Bibliofilskiego, w tym: Janusza Bartkowicza, Mateusza Otrębę, Kazimierza Machowinę, jak również późniejszych członków konfraterni: Dostojnego Makulaturzystę Tadeusza Grajpela, zwanego „zakonnym Gutenbergiem”, prof. Zbigniewa Majkowskiego, Brata Typografa z jego współpracownikami drukarzami: Janem Wszołkiem i Marianem Dziedzicem (dzisiaj Dostojnymi Makulaturzystami) z Pracowni Projektowania Książki i Typografii ASP w Krakowie, i wreszcie Kazimierza Wiśniaka, legendarnego współzałożyciela Piwnicy pod Baranami, scenografa, wziętego malarza i autora wielu książek, obecnie Brata Miniaturzysty, uhonorowanego Patentem ze Złoceniami, który swoim talentem służy Zakonowi od 10 lat.

Mając na uwadze wzrost zainteresowania ekslibrisem i doceniając wiedzę Andrzeja Znamirowskiego o historii ekslibrisu i technikach jego wykonywania oraz znając efekty prowadzonej przez niego „Galerii ekslibrisu” przy Domu Kultury „Podgórze”, wprowadziliśmy do naszej Konstytucji nowy tytuł w grupie „Suplementów w XXXII”, a mianowicie stanowisko w Zakonie „Brat Archiekslibrisofil”, powierzając mu tę funkcję.

Po 2007 r. wróciliśmy, na krótko, do „Stolika Bibliofilskiego” w „Hotelu Grand”, przy którym odbyliśmy kilka spotkań, a na dłużej pozostaliśmy w pięknej zabytkowej Sali Wiedeńskiej tego hotelu, w której miały miejsce nasze „zmyszenia” w latach 2007-2010, prowadzone w stosownej do miejsca atmosferze.

Dnia 19 lutego 2007 r. zmarła Urszula Waleria Witkiewiczowa, ostatnia Strażniczka „Gniazda Białego Kruka” i nieodżałowana Pieczętarz Odrodzonego Rycerskiego Zakonu Bibliofilskiego w Krakowie. Pochowana została we wspólnym grobie Witkiewiczów na

${ }^{5}$ Witryna internetowa działała do 4 maja 2009 r. z możliwością wprowadzania aktualnych informacji (WEBMASTER INIB UJ). Obecnie można korzystać z witryny, ale uzyskane informacje dotyczą tylko lat 1930-2009.

${ }^{6}$ Dorota Wierzbicka, ,Rycerski Zakon Bibliofilski z Kapitułą Orderu Białego Kruka (19302005) na tle informacji o bibliofilstwie w Internecie", praca magisterska napisana pod kierunkiem prof. UJ Marii Kocójowej w Instytucie Informacji Naukowej i Bibliotekoznawstwa, Kraków 2006. 
cmentarzu Rakowickim w Krakowie. Jej również poświęciliśmy okolicznościowy druk bibliofilski wydany w $2007 \mathrm{r}$.

Podczas „Imienin Książki” w marcu 2007 r. zaprezentowany został pierwszy numer czasopisma bibliofilów polskich „Akapit” z tekstem o Zakonie, a w październiku 2007 r. delegaci Zakonu uczestniczący w Ogólnopolskim Zjeździe Bibliofilów w Kaliszu złożyli sprawozdanie z obrad. W czasie Zjazdu Wielki Mistrz Zakonu wygłosił referat „Bibliofilstwo w kręgu Witkiewiczów", który znalazł się w Pamiętniku X. Ogólnopolskiego Zjazdu Bibliofilów w Kaliszu, wydanym w 2008 r.

Przy braku możliwości finansowych utrzymania przez Zakon „Gniazda Białego Kruka”, czyli mieszkania Witkiewiczów przy ul. Smoleńsk 9/2, oraz decyzji władz Akademii Sztuk Pięknych w Krakowie, z żalem i ze świadomością dotkliwej straty, jaką ponosi Kraków i krakowscy bibliofile, nastąpiła jego likwidacja, a archiwum, zgodnie z tradycją i ostatnią wolą Urszuli Witkiewiczowej, przejęte zostało i zabezpieczone przez Wielkiego Mistrza.

Zakon od 2008 r. stał się zakonem wędrownym, a Biały Kruk swoim rozeznaniem wybierał każdorazowo kolejne miejsce „zmyszenia”. Często wyznaczał przyjazne miejsce, którym jest do dzisiaj Pracownia Projektowania Książki i Typografii ASP w Krakowie. Mieści się ona w budynku przy ul. Smoleńsk 9, a prowadzona jest przez zasłużoną dla Zakonu Damę Książki dr Dorotę Ogonowską, teoretyka sztuki książki, scenografa, autorkę wystaw dotyczących projektowania książki, a także współautorkę, z Wielkim Mistrzem, nietypowych katalogów wystaw o książce organizowanych w Akademii Sztuk Pięknych w Krakowie i Muzeum Narodowym w Krakowie. Wielką życzliwość okazywał Zakonowi prof. Adam Wsiołkowski, wybitny malarz, rektor Akademii Sztuk Pięknych w latach 2008-2012, który uhonorowany został włączeniem do Zakonu jako Dostojna Makulatura. Biały Kruk wskazywał również Bibliotekę Jagiellońską, skąd wyszły Damy Książki; Danuta Bromowicz, autorka wielu wystaw promujących działania Zakonu i Aleksandra Cieślar. Natomiast dyrektor tej znakomitej książnicy prof. Zdzisław Pietrzyk, nadzwyczaj zasłużony dla Zakonu, pełni w nim zaszczytną funkcję Brata Arcykustosza.

Nie odmówiono Białemu Krukowi miejsca w budynku Archiwum Narodowego w Krakowie przy ul. Siennej, gdzie gospodaruje Dama Książki dr Kamila Follprecht. Biały Kruk potrafił nas zadziwić, wskazując na niezwykłe miejsce do odbycia naszego „zmyszenia”, którym okazał się „Dwór Czeczów” - Centrum Kultury Podgórza w dzielnicy Bieżanów przy ul. ks. Jerzego Popiełuszki. Znaleźliśmy nie tylko gościnę, ale również zostaliśmy serdecznie przyjęci przez panią Magdalenę Piędel w pomieszczeniach zamienionych na czytelnię i bibliotekę prof. Tadeusza Chrzanowskiego, która tam znalazła schronienie po jego śmierci.

Były też miejsca, które ze szczególną siłą zapadły w pamięć zarówno członkom konfraterni, jak i zaproszonym gościom. Takim miejscem okazał się Zamek Kmitów i Lubomirskich w Wiśniczu Starym. Dzięki staraniom prof. Wacława Waleckiego, Brata Bibliografa wielce zasłużonego dla Zakonu i ówczesnego burmistrza Wiśnicza Nowego Stanisława Gaworczyka, mieliśmy okazję przeżyć dwie biesiady z książką. Były to - „Majówka z książką" w 2010 r. oraz spotkanie, które odbyło się w dniu 10 października 2010 r. z okazji II Międzynarodowej Konferencji Naukowej „LIBRI RECOGNITI, Starodruki polskie w państwowych bibliotekach Rosji, Ukrainy, Białorusi i Litwy", organizowanej przez Centrum Badawcze Bibliografii Polskiej Estreicherów Uniwersytetu Jagiellońskiego 
i Muzeum Ziemi Wiśnickiej w Nowym Wiśniczu. Proponowane przez Zakon podjęcie prac nad stworzeniem z Wiśnicza Starego „Miasta Książki” i włączeniem go do grupy miast świata posiadających taki status, nie wyszło jednak, z powodów od nas niezależnych, poza wstępne rozważania.

Zwiększone zainteresowanie działalnością Zakonu, także przez piszących prace dyplomowe studentów Uniwersytetu Jagiellońskiego, spowodowało konieczność uporządkowania archiwum oraz pełniejszego dokumentowania bieżącej działalności. Wielki Mistrz powierzył kandydatowi do Zakonu Władysławowi Malcowi, właścicielowi zakładu fotograficznego, wykonywanie dokumentacji zdjęciowej z każdego spotkania i „zmyszenia”.

Dzięki wieloletniej współpracy z Towarzystwem Słowaków w Polsce i jego sekretarzem generalnym Ludomirem Molitorisem, a także drukarnią Towarzystwa, w której wykonujemy część ilustracyjną zaproszeń na „zmyszenia”, mieliśmy okazję biesiadować we wrześniu 2015 r. z przyjaciółmi bibliofilami słowackimi w pięknym obiekcie Centrum Kultury Słowackiej mieszczącym się w zabytkowej spiskiej wsi Nowa Biała.

Odrodzony Rycerski Zakon Bibliofilski nie obniżył lotów nawet pomimo tego, że kolejny rok działalności rozpoczął się dla niego wyjątkowo nieszczęśliwie. W dniu 17 stycznia 2011 r. zmarł nagle prof. Zbigniew Majkowski, Brat Typograf, niezwykle oddany Zakonowi kierownik Pracowni Projektowania Książki ASP w Krakowie. Został pochowany na cmentarzu Salwatorskim w Krakowie.

W czasie „Imienin książki” 4 marca 2011 r. został włączony do Zakonu Władysław Andreasik, współautor monumentalnego czterotomowego dzieła Jan Paweł II na znakach pocztowych świata ${ }^{7}$, podróżnik, autor artykułów drukowanych w prasie polonijnej, wydawca i propagator kolekcjonerstwa o tematyce sakralnej. W tym samym 2011 r. dostąpiliśmy zaszczytu uczestniczenia w XXVII Międzynarodowym Kongresie Bibliofilów, który odbywał się w dniach 18-25 września m.in. w Krakowie i Warszawie. Z tej okazji przygotowano specjalne zaproszenie na „zmyszenie” z krótką historią Zakonu w języku angielskim i ilustracją wykonaną przez Kazimierza Wiśniaka. Wielki Mistrz Jerzy Duda miał przyjemność rozmawiać z dr. T. Kimball Brookerem z USA, prezesem Association Internationale de Bibliophilie oraz w stroju rytualnym spotkać się z uczestnikami Kongresu podczas lunchu w Hotelu Copernicus, w czasie którego przekazał krótką informację o Zakonie ${ }^{8}$. Kilka miesięcy później brać bibliofilska z wielkim żalem żegnała na cmentarzu Rakowickim w Krakowie prof. Tadeusza Ulewicza, Brata Oratora, zmarłego 5 maja 2012 r., współtwórcę Odrodzonego Rycerskiego Zakonu Bibliofilskiego, wybitnego bibliofila, autora wielu prac naukowych, również dotyczących dziejów bibliofilstwa i drukarstwa krakowskiego.

\footnotetext{
${ }^{7}$ Marek Plewako, Władysław Andreasik, Jan Paweł II na znakach pocztowych świata, t. 1-4, Warszawa 2001-2009.

${ }^{8}$ Notatka o spotkaniu wraz z reprodukcją portretu Wielkiego Mistrza wykonanego przez artystę malarza Władymira Nikolina znalazła się w publikacji wydanej przez Association Internationale de Bibliophilie, zawierającej teksty referatów wygłaszanych podczas Kongresu oraz sprawozdanie z przebiegu obrad i spotkań, International Association of Bibliophiles: Transactions Poland. XXVIIth Congress Kraków Warsaw: Post-Congress Toruń, Pelplin, Gdańsk, wyd. i wstęp T. Kimball Brooker, Czech Republik 2017.
} 
Ostatnie lata przyniosły nam wydarzenia bez precedensu związane z przyjęciem do Zakonu wybitnych artystów i bibliofilów. W 2013 r. włączona została Alina Kalczyńska z Mediolanu, artystka wielokrotnie nagradzana na międzynarodowych wystawach, współtworząca w Europie ideę książki artystycznej (obecnie Dama Książki uhonorowana Patentem ze Złoceniami), dla której laudację przygotowała prof. Uniwersytetu Jagiellońskiego Maria Kocójowa9 . W 2017 r. uhonorowaliśmy podczas wyjątkowego „zmyszenia” - o czym później - Patentami Dostojnej Makulatury współtwórców i redaktorów jedynego obecnie w Polsce czasopisma bibliofilskiego „Akapit”, Romana Nowoszewskiego z miasta Błonie - redaktora naczelnego i Włodzimierza Rudnickiego - naczelnego grafika czasopisma z Łodzi. Dzięki nim w pierwszym numerze ukazał się artykuł o Zakonie ${ }^{10}$. Wymienieni redaktorzy są znanymi i cenionymi postaciami z kręgu miłośników ksiąg, którzy dołączyli do konfratrów spoza Krakowa wcześniej przyjętych do Zakonu. W grupie tej znaleźli się: Barbara Szornel-Dąbrowska z Kielc, autorka książek o Towarzystwie Miłośników Książki w Krakowie i korespondencji Tadeusza Przypkowskiego z Kazimierzem Witkiewiczem ${ }^{11}$; Helena Serocka z Pelplina i Tadeusz Serocki, dyrektor Wydawnictwa Diecezji Pelplińskiej „Bernardinum”, w którym wydano reprint jedynego polskiego egzemplarza Biblii Gutenberga, a także książkę autorstwa Tadeusza Eugeniusza Witkiewicza ${ }^{12}$. Wśród członków spoza Krakowa należy wymienić: Mieczysława Skinderowicza, prezesa Oddziału Śląskiego Towarzystwa Przyjaciół Książki w latach 1995-1998 z Katowic, prof. Janusza Kapuścika, dyrektora Głównej Biblioteki Lekarskiej w Warszawie oraz dr. Franciszka Kaszubę z Chrzanowa. W grupie tej znajduje się również zasłużona dla Zakonu Dama Książki dr Katarzyna Domańska z Bydgoszczy, pracownik naukowy Uniwersytetu im. Kazimierza Wielkiego, utrzymująca stały kontakt z Krakowem i do dzisiaj aktywnie uczestnicząca w pracach Zakonu.

Obowiązki związane z bieżącą działalnością Zakonu, przygotowywaniem „zmyszeń”, udziałem w spotkaniach i kontaktami z instytucjami i organizacjami skupiającymi miłośników ksiąg wykonywane są przez Wielkiego Mistrza Zakonu i jego najbliższych współpracowników, to znaczy Kanclerza, Pieczętarza Zakonu, Brata Miniaturzystę i Dostojnych Makulaturzystów z Pracowni Projektowania Książki. Prace Wielkiego Mistrza i Kanclerza prof. Politechniki Krakowskiej Andrzeja Gaczoła wspiera z właściwą sobie energią prof. Uniwersytetu Jagiellońskiego Piotr Dobosz, obecnie Pieczętarz Zakonu. Wykorzystując Jego profesjonalną wiedzę prawniczą i doświadczenie, przygotowaliśmy „Supplementum” do Ustawy Konstytucyjnej Rycerskiego Zakonu Bibliofilskiego z Kapitułą Orderu Białego Kruka w Krakowie. Konstytucja Zakonu opracowana w 1930 r. jest wieczna i nie może być zmieniana, a jedynie uszczegóławiana. Konstytucja po raz pierwszy wydana została drukiem w 1998 r. przez Tadeusza i Urszulę Witkiewiczów w 150 egzemplarzach numerowanych. Prace drukarskie wykonali pracownicy Pracowni Typograficznej w ASP Jan Wszołek

${ }^{9}$ Maria Kocójowa,Dama Ksiażki ze złoceniami Alina Kalczyńska-Scheiwiller, „Akapit” 2014, t. 9 , s. $60-64$.

${ }^{10}$ Jerzy Duda, Rycerski Zakon Bibliofilski w Krakowie, „Akapit” 2006, t. 1, s. 98-102.

${ }^{11}$ Barbara Szornel-Dąbrowska, Towarzystwo Miłośników Ksiqżki w Krakowie 1923-1962, Biblioteka Krakowska nr 143; eadem, Korespondencja Tadeusza Przypkowskiego z Kazimierzem Witkiewiczem 1961-1967, Kielce 2006.

${ }^{12}$ Tadeusz Witkiewicz, Niezwykłe ksiag miłowanie, proza i poezja, Pelplin 2002. 
i Marian Dziedzic. Oni też nadali opracowanemu w 2014 r. „Supplementum” formę druku bibliofilskiego wydanego metodą typograficzną. Konstytucja ta jest wręczana każdemu nowemu członkowi po jego uroczystym włączeniu do Zakonu.

Pierwsze egzemplarze „Supplementum” zostały wręczone Dostojnej Makulaturze Zbigniewowi Święchowi, reporterowi przeszłości, autorowi bestsellerów, laureatowi wszystkich możliwych nagród i wyróżnień - jak zapisano w patencie z października 2014 r. Następne egzemplarze wręczono w 2015 r. podczas uroczystego „zmyszenia” w Nowej Białej Damie Książki dr Kamili Follprecht z Archiwum Narodowego w Krakowie, autorce wielu publikacji prezentowanych w czasie spotkań oraz Dostojnej Makulaturze Hieronimowi Sieńskiemu, pracownikowi Biblioteki Głównej Akademii Górniczo-Hutniczej im. Stanisława Staszica i Piwnicy pod Baranami, autorowi wielu artykułów prasowych, wystaw i pokazów organizowanych w bibliotece, w tym także z udziałem naszych komilitonów.

Przyjacielskie kontakty nawiązane od 2012 r. pomiędzy Zakonem i Związkiem Monarchistów „Cracovia”, szczególnie z założycielem i Księciem Wielkiego Księstwa Krakowskiego Ryszardem hr. Bochenkiem-Dobrowolskim herbu Tępa Podkowa i jego małżonką Elżbietą z domu Żórawską, zaowocowały włączeniem obojga do Zakonu z tytułami Dostojna Makulatura i Dama Książki. Uroczyste wręczenie patentów miało miejsce w Sali posiedzeń Archiwum Narodowego w Krakowie dnia 11 marca 2016 r.

Do „zmyszeń” o szczególnym znaczeniu dla Zakonu odbywających się w ostatnim czasie zaliczamy „Imieniny Książki” w dniu 10 marca 2017 r. O jego wyjątkowości świadczą przede wszystkim goście uczestniczący w spotkaniu, merytoryczny program, osoby Probantów włączanych do Zakonu, a także miejsce obrad. Należy podkreślić, że „zmyszenie” odbyło się w pomieszczeniach na I piętrze Pałacu Larischa mieszczącym się na rogu ul. Brackiej i Franciszkańskiej. Jest to miejsce, w którym 83 lata wcześniej nastapiło uroczyste wręczenie Orderu Białego Kruka z Cymeliami ministrowi spraw zagranicznych Francji Louis Barthou. Uroczystość wręczenia Orderu odbyła się 24 kwietnia 1934 r. z udziałem prezydenta miasta Krakowa dr. Mieczysława Kaplickiego, Dostojników Zakonu i zaproszonych gości.

Tym razem w uroczystości „Imienin Książki” udział wzięli, poza konfratrami i Probantami, równie Dostojni Goście jak podczas wspomnianego nadawania Orderu Białego Kruka ministrowi Barthou. Wśród nich należy wymienić: prof. Franciszka Ziejkę, przewodniczącego Społecznego Komitetu Odnowy Zabytków Krakowa, rektora Uniwersytetu Jagiellońskiego w latach 1999-2005, autora wielu publikacji naukowych i książek, prof. Ewę Andrysiak, prezesa Towarzystwa Przyjaciół Książki z Kalisza również prof. Krzysztofa Walczaka i Ewę Obała z Towarzystwa Przyjaciół Książki z Kalisza, Mieczysława Bielenia z Towarzystwa Bibliofilów Polskich z Warszawy, Andrzeja Cłapińskiego i Jacka Jurczakowskiego z Towarzystwa Przyjaciół Książki z Łodzi. Licznie przybyli przedstawiciele krakowskich antykwariuszy: Janusz Pawlak, Anna Stecka, Sara Śmiłek i Antoni Stapor. Zaszczycili swoją obecnością również: dr Tadeusz Filar, dyrektor Muzeum Uniwersytetu Ekonomicznego, autor licznych prac naukowych oraz Magda Koziak-Podsiadło z Pracowni Projektowania Książki ASP w Krakowie. Przybyli również przedstawiciele Ludu Bibliofilskiego, m.in. Maciej Rudy, Sylwia Puchała, Jan Piaskowski, Roma Habowska-Święch, prof. Iwona Niżnik-Dobosz. 
Głównym punktem programu „Imienin Książki” był akt włączenia do Zakonu dwóch wybitnych Probantów, poprzedzony odczytaniem laudacji, czyli sprawozdania z wyników badań cnót bibliofilskich każdego z nich. Laudację dla Romana Nowoszewskiego przygotował Brat Arcykustosz Zdzisław Pietrzyk, a dla Włodzimierza Rudnickiego Brat Miniaturzysta z Patentem ze Złoceniami Kazimierz Wiśniak.

Interesującą częścią spotkania była prezentacja fragmentu pracy doktorskiej Magdy Koziak-Podsiadło o zbiorach introligatorskich znajdujących się w Pracowni Projektowania Książki, a także wystawa reprintów dawnych książek niemieckojęzycznych.

Nad sprawnym przebiegiem „Imienin” czuwał „gospodarz” lokalu prof. Piotr Dobosz, prodziekan ds. studiów administracyjnych z małżonką prof. Uniwersytetu Jagiellońskiego Iwoną Niżnik-Dobosz.

Każde „zmyszenie” organizowane przez Odrodzony Rycerski Zakon Bibliofilski w Krakowie posiadało stosowne ilustrowane zaproszenie z częścią tekstową utrzymaną na ogół w tonie informacyjno-żartobliwym. Zaproszenia redagowane były wspólnymi siłami przez Tadeusza i Urszulę Witkiewiczów do 2001 r., następnie przez Urszulę Witkiewiczową i Jerzego Dudę, a od 2007 r. przez Wielkiego Mistrza w konsultacji z wybranymi Bratem lub Damą Książki. Jak wspomniałem wcześniej, ilustracje wykonywane były przez artystów plastyków, a od 2008 r. przez Kazimierza Wiśniaka i są obiektami kolekcjonerskimi, a także dokumentami prezentowanymi na wystawach i pokazach. Zadbaliśmy o to, aby na każdym „zmyszeniu” była część merytoryczna, którą stanowią na ogół: krótki referat, wspomnienia, pokaz cymeliów z komentarzem, prezentacja rarytasów z własnych zbiorów czy nowo pozyskanych, wygłoszenie recenzji wybranej książki, opowieść o przygodzie z książką. Ta część stała się tradycją spotkań i otrzymała nazwę „Przechwałki bibliofilskie”. Referaty, prezentacje i pokazy realizowane były zarówno przez konfratrów, jak i zaproszonych gości, znanych miłośników ksiąg.

Aktywny udział w ,zmyszeniach” brały, na zaproszenie Zakonu, zarówno osoby duchowne, jak i pracownicy naukowi z różnych ośrodków naukowych, bibliofile i ,słudzy książki”, antykwariusze, księgarze i graficy książkowi. Bracia Zakonni, Kapitałki, Damy Książki i Dostojni Makulaturzyści zawsze z uwagą i atencją wysłuchiwali autorów książek i znawców sztuki książki. W 1993 r. miała miejsce prelekcja Anny Rybczyńskiej, zasłużonej działaczki żeglarstwa polskiego o kapitanie Władysławie Wagnerze. W 1994 r. w „,zmyszeniu” brał udział Henryk Babral, kierownik wydawnictwa „Secesja”, w którym drukowany był „Rocznik Krakowski”, czasopismo Towarzystwa Miłośników Historii i Zabytków Krakowa oraz wybrane cenne pozycje polskiej literatury w wydaniu bibliofilskim. W następnym roku komilitoni mogli wysłuchać gawęd prof. Antoniego Stanisława Kleczkowskiego, bibliofila, humanisty, ponadto znawcy polskiej książki technicznej dr. Jerzego Krawczyka, który mówił o historii najstarszej biblioteki technicznej w Szkole Górniczo-Hutniczej oraz Zdzisława Dyla, właściciela jedynej wówczas księgarni książek technicznych w Krakowie, o najciekawszych księgach z tej dziedziny. Również w 1995 r. Władysław Berbelicki przypomniał na „Imieninach Książki” postać Karola Estreichera Młodszego, a Ryszard Terlecki, przy okazji kolejnego ,zmyszenia”, podzielił się wspomnieniami o swoim ojcu Olgierdzie, autorze jedynej wówczas pracy na temat Zakonu ${ }^{13}$. W następnych latach go-

\footnotetext{
${ }^{13}$ Olgierd Terlecki, Piękna Polaków zabawa czyli Kapituła Orderu Białego Kruka, Warszawa
} 1979. 
ściliśmy kolejnych prelegentów, w tym: Marka Sosenkę, zwanego w Krakowie „królem kolekcjonerów”, z kontrowersyjnym tematem prelekcji „Współtworzenie książki, czyli o... pocztówce"; ks. dr. Andrzeja Boksińskiego z opowieścią o różnych przypadkach Jej Mości Książki i o własnej bogatej bibliotece; prof. dr. Piotra Hańczakowskiego, bibliofila i kolekcjonera „cracovianów”, który prezentując swoje zbiory, opowiadał o galicyjskich przygodach książki; Tadeusza Lohna, byłego kierownika literackiego „Teatru 38” w Krakowie; Małgorzatę Krzysztofikową; Ojca Gwardiana Andrzeja Zająca z Zakonu Franciszkanów podejmującego temat „Słowo pisane u św. Franciszka”; prof. Renardę Ocieczkową, która przybliżyła życie Panien Lubomirskich i ich księgozbiorów; dr. Arkadiusza Adamczuka z Katolickiego Uniwersytetu Lubelskiego Jana Pawła II, który opowiadał o miniaturach z Dekretu Gracjana; Józefa Kwolka, najwierniejszego Probanta Zakonu, który na kolejnych „,zmyszeniach” od 2009 r. prezentował wybrane wiersze ze swoich 6 tomików wydanych w „formie poezji humorystycznej” - jak sam twierdził; Janusza Pawlaka, który ze swadą opowiedział o modyfikacji definicji książki na przestrzeni wieków w referacie „Czy to książka czy nie książka”; Ryszarda hr. Bochenka-Dobrowolskiego z Iwanowic z prezentacją dorobku edytorskiego oraz czasopisma „Wiadomości Monarchistyczne”; Magdalenę Piędel z ciekawą i barwnie opowiedzianą historią rodziny Czeczów, jej wkładem w rozwój Krakowa i o rodzinnych włościach, w tym również na terenie Bieżanowa.

$\mathrm{Na}$ „zmyszeniach” promowaliśmy książki wydane przez naszych konfratrów i Damy Książki, ale również innych autorów. Do wyjątkowych i atrakcyjnych promocji zaliczamy tę z listopada 2002 r., w czasie której otrzymaliśmy karty reprintu polskiego egzemplarza Biblii Gutenberga. Tadeusz Serocki, reklamując dzieło, zauroczył zebranych opowieścią o pracach nad przygotowaniem reprintu i problemach z tym związanych, a także o efektach i zainteresowaniu miłośników ksiąg na świecie tym unikatowym dziełem ${ }^{14}$.

W 2012 r. promowaliśmy książkę zespołu autorskiego złożonego z najsłynniejszych na świecie krakauerów Mieczysława Czumę i Leszka Mazana, ilustrowaną przez Brata Miniaturzystę Kazimierza Wiśniaka ${ }^{15}$. W czasie marcowego spotkania, czyli na „Imieninach Książki" również w 2012 r. promowaliśmy tomiki wierszy poetki Beaty Kurek z Biblioteki Jagiellońskiej. Do dzisiaj z uznaniem wspominam przypadkowe, ale i niezwykłe spotkanie z panią Beatą w Muzeum Polskim w Rapperswilu, dzięki któremu mogłem z żoną i przyjacielem obejrzeć muzealną bibliotekę.

Promocje książek napisanych i niekiedy wydanych własnym sumptem przez Braci Zakonnych i Damy Książki w czasie naszych „zmyszeń” miały jednak zawsze swój odrębny, niepowtarzalny klimat, atmosferę i dawały autorom, ale i uczestnikom poczucie bycia wśród rodziny miłośników ksiąg, akceptujących ideę zawartą w naszej Konstytucji i respektujących akt przyrzeczenia, które składa każdy włączany do Zakonu: „Wierność książce, Zakonowi i Konfratrom w każdej potrzebie życia". Najwcześniej, bo w latach 1994-1997, swoje książki ${ }^{16}$ prezentowała krakowska reporterka, autorka poczytnych

${ }^{14}$ Na zaproszenie Tadeusza Serockiego Urszula Witkiewiczowa i Jerzy Duda uczestniczyli w pokazie reprodukowania stron egzemplarza Biblii Gutenberga bez rozpinania stron, realizowanym w wydawnictwie „Bernardinum” w Pelplinie przez specjalistów z Japonii i na ich sprzęcie.

${ }^{15}$ Mieczysław Czuma, Krakowskie abecadło, Kraków 2012.

${ }^{16}$ Ewa Owsiany, Bezdomność Boga, Kraków 1993; eadem, Nic straconego, Kraków 1997. 
publikacji, a przede wszystkim tekstów o Odrodzonym Rycerskim Zakonie Bibliofilskim redaktor Ewa Owsiany.

W 2002 r. na październikowym „zmyszeniu” komilitoni mieli okazję zapoznać się z książką napisaną przez Damę Książki Barbarę Szornel-Dąbrowską o Towarzystwie Miłośników Książki w Krakowie. Po 2003 r. liczba promowanych książek wyraźnie wzrosła, w tym również zasługa dwóch autorów, Damy Książki Marzeny Florkowskiej oraz Kazimierza Wiśniaka. W latach 2004-2007 Marzena Florkowska prezentowała na „zmyszeniach” oraz przy „Stoliku Bibliofilskim” w „Grand Hotelu” trzy książki ${ }^{17}$, w tym jedną pisaną wspólnie z mężem Markiem.

W 2008 r. ilustrację do zaproszenia na „Imieniny Książki” wykonał po raz pierwszy Kazimierz Wiśniak. Był gościem na spotkaniu, ale poproszony przez Wielkiego Mistrza o zabranie głosu opowiedział interesująco o książkach, których był autorem i pracach innych autorów dotyczących jego działalności artystycznej. Szczególnym zainteresowaniem cieszyła się opowieść o książkach poświęconych jego ukochanej Lanckoronie.

W czasie październikowego ,zmyszenia” w 2009 r. Probant Władysław Andreasik, obecnie Dostojna Makulatura, opowiadał o pracach nad 4. tomem wspomnianego wcześniej dzieła Jan Paweł II na znakach pocztowych świata, którego jest współautorem. Opowieść o pracy nad dziełem wzbudziła uzasadnione zainteresowanie komilitonów, bowiem uzupełniana była relacjami z podróży do wielu krajów leżących na różnych kontynentach w celu zdobywania oryginalnych i niekiedy unikatowych walorów filatelistycznych związanych z osobą i pontyfikatem papieża Jana Pawła II.

„Imieniny Książki” w 2010 r. stały się ucztą duchową dla licznie przybyłych do Pracowni Projektowania Książki i Typografii w ASP komilitonów. Książką, która zachwyciła i o której ze swadą i znawstwem opowiadał prof. Zdzisław Pietrzyk, obecnie Brat Arcykustosz, był album Skarby Biblioteki Jagiellońskiej ${ }^{18}$. Zaprezentowano w nim największe skarby piśmiennictwa, nauki i kultury przechowywane w Bibliotece Jagiellońskiej. Na ponad 170 stronach pokazano reprodukcje unikatowych rękopisów, starych druków, grafik, map, atlasów i muzykaliów. Całość zrealizowana w wytwornej szacie graficznej, poprzedzona została tekstem zawierającym historię szacownej i znanej książnicy.

Dzień 4 marca 2012 r. stał się podwójnym świętem zarówno Pani Książki, jak i Odrodzonego Rycerskiego Zakonu Bibliofilskiego. W tym dniu bowiem włączona została do Zakonu dr Dorota Ogonowska prowadząca Pracownię Projektowania Książki i Typografii z tytułem Dama Książki, wielce zasłużona dla Zakonu, a także obchodziliśmy „Imieniny Książki” oraz imieniny Kazimierza. Brat Kazimierz Wiśniak otrzymał stosowne czołobitności od konfratrów, którzy oczekiwali na spotkanie z dziełem życia ${ }^{19}$ jubilata, zaanonsowanym w drukowanym zaproszeniu na ,zmyszenie”. Dzieło, zrealizowane w Wydawnictwie „Vandre” naszego Dostojnego Makulaturzysty Władysława Andreasika, zrobiło nadzwyczajne wrażenie na komilitonach. Księga in folio, z ilustracjami w kolorze, zawiera autobiografię autora ilustrowaną jego projektami scenograficznymi, pracami graficznymi

${ }^{17}$ Marzena Florkowska, Ojciec Piotr-benedyktyn, karmelita, rekluz, Kraków 2004; Marzena i Marek Florkowscy, Kameduli, Kraków 2005; O. Piotr Rostworowski. Myśli, powiedzenia, anegdoty, wybór i oprac. Marzena Florkowska, Kraków 2007.

${ }^{18}$ Skarby Biblioteki Jagiellońskiej, red. Zdzisław Pietrzyk, Kraków 2009.

${ }^{19}$ Kazimierz Wiśniak, Życie ze sztukq splecione, Kraków 2012. 
i malarskimi. Z kart książki przebija talent autora, jego wszechstronność artystyczna od rysunku do scenografii, znakomity warsztat, a przede wszystkim pracowitość oraz radość życia, optymizm i wiara w ludzką dobroć. Sensacją było ujawnienie faktu, że książka została przez autora wykonana ręcznie, pięknym pismem kaligraficznym i uzyskała postać zwoju, na kształt zwojów egipskich, o długości ponad 10 metrów. W 2015 r. autor uroczyście przekazał manuskrypt do Biblioteki Jagiellońskiej.

W 2012 r. Odrodzony Rycerski Zakon Bibliofilski w Krakowie obchodził jubileusz 20-lecia działalności. Z tej okazji otrzymaliśmy specjalny adres przygotowany drukiem przez Włodzimierza Rudnickiego i Marka Kryma o szczególnych walorach typograficznych i bibliofilskich. Adres przekazany przez bibliofilów warszawskich ze stosownymi życzeniami jest podpisany przez wybitnych bibliofilów: prof. Edwarda Towpika, prezesa Towarzystwa Bibliofilów Polskich, Mieczysława Bielenia i Romana Nowoszewskiego.

Po raz pierwszy gościliśmy na ,zmyszeniu” Ryszarda hr. Bochenka-Dobrowolskiego z małżonką Elżbietą, artystę i autora interesujących książek z zakresu historii oraz wydawcę i redaktora czasopisma „Wiadomości Monarchistyczne” z Iwanowic Włościańskich, który przybliżył komilitonom ideę Związku Monarchistów „Cracovia”.

W czasie uroczystych obchodów „Imienin Książki” 4 marca 2014 r. promowano książki znanych już Czytelnikom autorek, Ewy Owsiany ${ }^{20}$ i Marzeny Florkowskiej ${ }^{21}$. Natomiast na spotkaniu październikowym w 2014 r. Kazimierz Wiśniak opowiadał o przygodach związanych z kolejną swoją pracą ${ }^{22}$, w której przedstawił dzieje zimowego festiwalu, jarmarku w Lanckoronie oraz przyjętego w niej zwyczaju honorowania ludzi zasłużonych dla tej miejscowości tytułem „Anioła Lanckorony”. Otrzymał go Kazimierz Wiśniak jako pierwszy wraz z tytułem Honorowy Obywatel Lanckorony w 2004 r.

Nadzwyczajne ,zmyszenie” odbyło się w maju 2014 r., anonsowane oryginalnym zaproszeniem z kopią rysunku Aliny Kalczyńskiej23. W czasie ,zmyszenia” komilitoni mogli zapoznać się z wydawnictwami bibliofilskimi w opracowaniu Aliny Kalczyńskiej, zawierającymi oryginalne dzieła grafików polskich, wydawane w cyklu Serie incisione originali di artisti polacchi zainicjowanym przez włoskiego wydawcę Vanni Scheiwillera w jego oficynie All'Insegna del Pesce d'Oro. Promocja tego wydawnictwa w komplecie, trudno osiągalnego na rynku książki artystycznej, była wydarzeniem jedynym w swoim rodzaju. Podczas tej uroczystości Ryszard hr. Bochenek-Dobrowolski odznaczył Wielkiego Mistrza Zakonu Medalem „Stanisława Augusta Poniatowskiego” autorstwa prof. Czesława Dźwigaja, wybitym z okazji 15. rocznicy Wielkiego Księstwa Krakowskiego Związku Monarchistów „Cracovia”.

W 2015 r. rozpoczęły się przygotowania do prezentacji założeń obszerniejszej pracy na temat ekslibrisu i jego współczesnej roli w bibliofilstwie, której autorem miał być Andrzej Znamirowski, w Zakonie Brat Archiekslibrisofil (autorem tej tytulatury był Brat Orator prof. Tadeusz Ulewicz). Przygotowania przerwane zostały ze względu na chorobę autora,

${ }^{20}$ Ewa Owsiany, Rekolekcje rabczańskie ks. Karola Wojtyly, Kraków 2014.

${ }^{21}$ Marzena i Marek Florkowscy, Ludwik Zarewicz miłośnik Krakowa i przyjaciel kamedułów, Kraków 2014.

${ }^{22}$ Kazimierz Wiśniak, Anioł w miasteczku, Kraków 2014.

${ }^{23}$ Rysunek pochodzi ze szkicownika Aliny Kalczyńskiej, który wypełniony jest rysunkami białego kruka wykonanymi w 2013 r. w Otranto, miejscowości letniego wypoczynku artystki. 
która okazała się nieuleczalna i wyjątkowo szybko postępująca. Brat Andrzej zmarł 15 października 2015 r. i został pochowany na cmentarzu Rakowickim w Krakowie.

„Zmyszenie” z okazji „Imienin Książki” w 2016 r. przyniosło nam promocję dwóch książek: o Pamiętniku Mariana Dydyńskiego ${ }^{24}$ mówiła dr Kamila Follprecht, zastępca dyrektora Archiwum Narodowego w Krakowie, a Kazimierz Wiśniak przedstawił swoją książkę $e^{25}$.

27 czerwca 2016 r. zmarł najmłodszy stażem przedstawiciel Dostojnej Makulatury, Ryszard hr. Bochenek Dobrowolski, którego żegnaliśmy z bólem dnia 1 lipca na cmentarzu Podgórskim w Krakowie.

Wśród znamienitych autorów książek promujących swoje dzieła podczas „zmyszeń” dał się również poznać Wielki Mistrz Zakonu, który tak zainspirował Brata Miniaturzystę tytułem swojej skromnej publikacji, wydanej własnym sumptem ${ }^{26}$, że ten ostatni tytuł jej umieścił na urokliwej ilustracji zaproszenia na „Imieniny Książki” w 2013 r. W ostatnim czasie spod pióra Wielkiego Mistrza wyszła również bogato ilustrowana, również w kolorze, publikacja o historii Zakonu ${ }^{27}$, która powstała z inspiracji śp. Urszuli Witkiewiczowej, także przy wsparciu merytorycznym i duchowym prof. Marii Kocójowej. Książka promowana była w czasie ,zmyszenia” w „Dworze Czeczów” w 2016 r.

Na spotkaniach Odrodzonego Rycerskiego Zakonu Bibliofilskiego promowano zarówno książki nowo wydane, jak i przypominano pozycje, szczególnie autorstwa naszych Braci, Dam Książki i Dostojnej Makulatury, o których warto pamiętać. Przedstawiano zatem tytuły poczytnych książek takich autorów, jak np. śp. prof. Tadeusza Ulewicza, Zbigniewa Święcha, Kamili Follprecht, Ewy Owsiany i Marzeny Florkowskiej, jak również wydawnictwa pod redakcją prof. Marii Kocójowej, będące zbiorami referatów konferencji organizowanych przez Instytut Informacji Naukowej i Bibliotekoznawstwa UJ. Jedne zbiory były w formie ,papierowej”, inne zapisane na nośniku elektronicznym w formie CD lub DVD.

„Zmyszenia” organizowane obowiązkowo dwa razy do roku, to znaczy około 4 marca, czyli w „Imieniny Książki” i 21 października w rocznicę śmierci założyciela i pierwszego Wielkiego Mistrza Zakonu Kazimierza Witkiewicza, często uzupełniane były spotkaniami okazjonalnymi, najczęściej podczas wernisaży wystaw, odczytów, prelekcji, działań animatorskich i imprez organizowanych przez różne instytucje, ale z udziałem naszych konfratrów. Spotkania odbywały się m.in. podczas wystaw przygotowywanych przez Bibliotekę Jagiellońską, Bibliotekę Główną AGH w ramach cyklu inicjowanego przez Zakon, a mianowicie „Miłość do ksiąg niejedno ma imię”. Były to wystawy „Bibliofilatelia” i „Bibliofilatelia 2” organizowane przez Bibliotekę Jagiellońską i Odrodzony Rycerski Zakon Bibliofilski w listopadzie 2000 r. oraz w grudniu 2001 r. W Bibliotece Głównej AGH spotkania organizowane były przy okazji wystaw: „Książka i biblioteka w filatelistyce” w 2015 r., „O bibliotece w bibliotece” w 2016 r. i „Kazimierz Wiśniak - mistrz detalu i precyzji” w 2016 r. Widywaliśmy się w węższym gronie także z okazji prezentacji

${ }^{24}$ Pamiętnik Mariana Dydyńskiego z Raciborska (1843-1920), oprac. Karolina Gołąb-Malowicka, Kraków 2015.

${ }^{25}$ Kazimierz Wiśniak, Izdebnik w legendzie, Kraków 2016.

${ }^{26}$ Jerzy Duda, Czy Pan Bóg lubi znaczki, Kraków 2013.

${ }^{27}$ Idem, Rycerski Zakon Bibliofilski z Kapituła Orderu Białego Kruka 1930-1973, Kraków 2016. 
sztuki drzeworytniczej i typograficznej, podczas warsztatów i szkoleń prowadzonych przez Dostojną Makulaturę Tadeusza Grajpela w Krakowie, w tym również w Bibliotece Jagiellońskiej. Tadeusz Grajpel jest wyjątkowym i rozpoznawalnym w kraju członkiem naszego Zakonu z własną prasą typograficzną zbudowaną na wzór Gutenberga, doświadczeniem i praktyką w zakresie sztuki drzeworytniczej, specjalizującym się w sfragistyce. Wykonane przez niego odbitki drzeworytnicze wykorzystywane były m.in. do zaproszeń oraz jako kartki świąteczne wysyłane do konfratrów.

„Zmyszenia” Odrodzonego Rycerskiego Zakonu Bibliofilskiego mają swój niezmienny rytuał dostosowywany niekiedy do okoliczności i miejsca spotkania. Czas trwania nie jest limitowany i bywało, że biesiada trwała nawet 3 godziny, na ogół przy aplauzie uczestników, bowiem poruszane tematy, przechwałki bibliofilskie, ożywiona dyskusja i wymiana zdań, nawet mową wiązaną, pozwalały zapomnieć o upływającym czasie. W takich sytuacjach nadwątlone siły konfratrów ratowane były domowymi wiktuałami, cienkuszem galicyjskim (zwanym również galilejskim) i smakołykami. W „Gnieździe Białego Kruka” rolę gospodyni spełniała Urszula Waleria Witkiewiczowa, która przygotowywała miejsce dla konfratrów - co nie było łatwe, bowiem wymagało przemeblowywania mieszkania, wyniesienia sprzętów i mebli i wniesienia dodatkowych stołów i krzeseł - oraz poczęstunek. W przygotowywaniu pomieszczenia pomagali życzliwi pracownicy Akademii Sztuk Pięknych w Krakowie. Cienkuszem galicyjskim zwano herbatę powszechnie znaną ze swej jakości, bowiem preparowana była z kilku gatunków i parzona w sposób znany tylko Kapitałce, później Pieczętarzowi i Strażniczce „Gniazda Białego Kruka”, Urszuli. Trunki pojawiały się na stole bardzo rzadko. Wino serwowane było wyjątkowo i przy szczególnych okazjach, bowiem w „Gnieździe Białego Kruka” panowała abstynencja - o czym informowała stosowna wywieszka na drzwiach wejściowych. Wszystko za sprawą Tadeusza Witkiewicza, który działał przez długi czas w Stowarzyszeniu Przeciwalkoholowym „Błękitny Krzyż”. Ciasta i smakołyki były od początku działalności Odrodzonego Zakonu dziełem zarówno Urszuli, jak i Kapitałek, w tym głównie Heleny Skarbińskiej. Później „zaopatrzenie” w „smakołyki bibliofilskie” spadało na Urszulę Witkiewiczową, ale pomoc nieśli chętni zawsze konfratrzy, przede wszystkim Damy Książki. Pierwszy poważny problem z organizacją spotkań pojawił się w 2003 r., kiedy w Akademii Sztuk Pięknych w Krakowie zdecydowano zaanektować pomieszczenie będące kuchnią z przeznaczeniem jej na magazyn książek dla biblioteki Akademii. Konieczny stał się remont mieszkania wynajmowanego przez Witkiewiczów (w tamtym czasie już tylko przez Urszulę Witkiewiczową) w celu zapewnienia poważnie już chorej Urszuli niewielkiego pomieszczenia kuchennego.

Po 2007 r., kiedy nasz Zakon stał się Zakonem wędrownym, wiele spraw uległo modyfikacji. „Zmyszenia” w krakowskim „Grand Hotelu” miały bogatą oprawę kulinarną, a serwowane dania i ciasta podawane przez obsługę kelnerską wprowadzały powiew „,wielkiego świata”. Korzystając z uprzejmości i względów, które żywił do Zakonu dyrektor Robert Mrzygłód, mogliśmy poczuć coś z atmosfery spotkań z okresu II Rzeczpospolitej, kiedy przy „Stoliku Bibliofilskim” znajdującym się naprzeciwko „Stolika Profesorskiego” siadywali krakowscy luminarze sztuki i kultury. Wspomnienia o tych czasach znalazły się w wywiadzie przeprowadzonym z Robertem Mrzygłodem przez Damę Książki Ritę Pagacz-Moczarską i wydrukowanym w czasopiśmie „Alma Mater”. W czasie „zmyszeń” w Pracowni Projektowania Książki ASP w Krakowie zaopatrzeniem i organizacją stołu bie- 
siadnego zajmował się improwizowany zespół złożony z absolwentek Akademii Sztuk Pięknych w Krakowie, w skład którego wchodziły panie Magdalena Koziak i Natalia Nowacka, zwany popularnie ,zespołem cateringowym”.

Z czasem zmieniało się menu na „zmyszeniach”. W 2002 r. pojawiły się na stole biesiadnym „myszki bibliofilskie”. Autorką niezwykłych ciasteczek wykonanych z ciasta piernikowego na prawdziwym miodzie gorczańskim, dojrzewającego przez dwa tygodnie, jest Wielkomistrzyni Halina, czyli żona Wielkiego Mistrza. Zauroczona kształtem myszki projektu Wielkiego Mistrza Kazimierza sprzed 80 lat, postanowiła zrobić blaszaną formę w kształcie myszy z pomocą znajomego blacharza pana Stanisława, i wyciskać przy jej pomocy ciasteczka. Polukrowane na biało robiły furorę, a niezjedzone podczas spotkania były zabierane na pamiątkę, długo zachowując zapach piernika. Ciasteczka w formie myszek bibliofilskich doczekały się Atestu przygotowanego w formie druku bibliofilskiego przez Włodzimierza Rudnickiego i Romana Nowoszewskiego w 2010 r. Od 2016 r. „Myszki bibliofilskie" uzupełniane są przez autorkę ciasteczkami w kształcie białego kruka.

W 2011 r. pojawiła się na stole biesiadnym nowość, która została entuzjastycznie przyjęta przez konfratrów, a mianowicie ciasto a la Veronka. Autorką wyśmienitego wypieku drożdżowego, przygotowywanego według receptury okrytej tajemnica, jest Weronika Łodzińska-Duda, a ciasto na kolejne ,zmyszenia” było przygotowywane wpierw w warunkach domowych, a następnie w znanej i wytwornej krakowskiej restauracji „Pod Aniołami”.

Szczególne miejsce w działalności Odnowionego Rycerskiego Zakonu Bibliofilskiego zajmuje Chór Cecyliański (Stowarzyszenie Chór Cecyliański w Krakowie) i jego kolejni prezesi: śp. Stanisław Skarbiński, który piastował funkcję Pieczętarza Zakonu, Jan Kosowski, Piotr Różycki, Janusz Adamowski, obecnie Edward Jordan. Chór Cecyliański wykonywał przy wielu okazjach „Hymn Bibliofilski” skomponowany w 1934 r. przez Kazimierza Garbusińskiego do słów Justyna Sokulskiego. Chór śpiewał na mszach żałobnych Zakonnych Dostojników Tadeusza Witkiewicza i Urszuli Witkiewiczowej, również czcząc rocznice śmierci swoich członków, m.in. Stanisława Skarbińskiego i wspomnianego wcześniej Probanta Józefa Kwolka. Przede wszystkim zaś uświetniał msze św. odprawiane corocznie w bazylice Ojców Franciszkanów za założyciela Zakonu i pierwszego Wielkiego Mistrza Kazimierza Witkiewicza, później za Tadeusza i Urszulę Witkiewiczów, a od 2009 r. również za zmarłych bibliofilów z Odrodzonego Zakonu.

Hymnem bibliofilskim wykonywanym przez Chór Cecyliański i odtwarzanym w przeszłości z różnych nośników dźwięków rozpoczynane jest każde „zmyszenie”28. Niska jakość nagrania i stopniowe zużywanie się taśmy wpływały negatywnie na odbiór hymnu przez Probantów i przedstawicieli Ludu Bibliofilskiego nieznających jego słów. Wobec tego podjęta została decyzja o studyjnym nagraniu. Dzięki dr Justynie Duda-Krane z Akademii Muzycznej w Krakowie hymn bibliofilski został nagrany dnia 17 lutego 2016 r. w studio nagrań Akademii Muzycznej w wykonaniu czterech członków chóru Capelli Cracoviensis: Karola Kusza, Sebastiana Szumskiego, Szczepana Kosiora i Marka Opaski. Chór Cecyliań-

${ }^{28}$ Od 1992 r. hymn odtwarzano z taśmy magnetofonowej, później od 2002 r. z płyty CD, na którą został przegrany z taśmy magnetofonowej dzięki współpracy z Radiem Kraków i z pomocą Marzeny Florkowskiej. 
ski co roku wykonuje hymn podczas mszy św. w bazylice Ojców Franciszkanów w rocznicę śmierci Kazimierza Witkiewicza.

Ćwierć wieku istnienia i działalności Odrodzonego Rycerskiego Zakonu Bibliofilskiego w Krakowie stanowi już znaczący okres w dziejach Zakonu, który w 2020 r. będzie obchodził swoje 90-lecie. Mam nadzieję, że nic nie stanie na przeszkodzie, aby jubileusz obchodzony był hucznie, a informacje o nim odnotowały co ważniejsze periodyki bibliofilskie całego świata, o czasopismach i dziennikach nie wspominając.

Przez 25 lat odczuwaliśmy skromne zainteresowanie prasy krajowej i zagranicznej Odrodzonym Zakonem, zarówno jego działalnością i najnowszą historią, jak i tematami inspirowanymi miłością do ksiąg, do których zaliczamy działania pod hasłem „Miłość do ksiąg niejedno ma imię". Pisała o Zakonie i Jego Dostojnikach codzienna prasa krakowska „Gazeta Krakowska”, „Echo Krakowa”, „Czas Krakowski”, „Gazeta Wyborcza”. Artykuł o Zakonie pojawił się również w prasie polonijnej. Informacje i obszerniejsze artykuły drukowały także tygodniki i miesięczniki, jak: „Przekrój”, „Gość Niedzielny”, a czasopismo Uniwersytetu Jagiellońskiego „Alma Mater” poświęcało wiele miejsca na prezentację działalności Zakonu i jego konfratrów. Pisano często o Zakonie w roczniku Towarzystwa Bibliofilów Polskich „Akapit”.

Informacje o Zakonie pojawiały się również w prasie zagranicznej, głównie w czasopismach bibliofilskich. Pisano o Zakonie oraz wykorzystywano teksty konfratrów. Obszerniejszy tekst wydrukowano w biuletynie wydawanym przez Towarzystwo Bibliofilów Czeskich w Pradze „Zprawy” w 2002 r. W tym samym roku informację o nim podano w wydawnictwie Stacji Naukowej Polskiej Akademii Nauk w Wiedniu „Witryna Internetowa". Obszerny, bogato ilustrowany artykuł, autorstwa Brata Bibliografa prof. Wacława Waleckiego znalazł się w rosyjskim czasopiśmie bibliofilskim „Pro Knigi” pt. Kak ja stat wysokocztimoj makulaturoj w numerze z 2007 r. W 2011 r. ukazał się artykuł o Zakonie autorstwa Wielkiego Mistrza w litewskim czasopiśmie „tarp KNYGU” w tłumaczeniu Marij Ivanovic.

O Zakonie i jego Dostojnikach napisano cztery prace dyplomowe. W jednej z nich, wspomnianej wcześniej, znalazło się opracowanie, na podstawie którego utworzono witrynę internetową, a autorka, Dorota Wierzbicka, przygotowała artykuł drukowany w „Alma Mater”29. W 1996 r. Kinga Mackiewicz zrealizowała pracę magisterską „Tadeusz Eugeniusz Witkiewicz - Wielki Mistrz Rycerskiego Zakonu Bibliofilskiego"30. Paulina Nieradko napisała w 2009 r. pod opieką prof. dr. hab. Zdzisława Pietrzyka pracę magisterską „Działalność bibliofilska i wystawiennicza Jerzego Dudy na tle ruchu bibliofilskiego w Krakowie” ${ }^{31}$. W kolejnej pracy zatytułowanej „Działalność Odrodzonego Ry-

${ }^{29}$ Dorota Wierzbicka, Bibliofilstwo i internet. Internet - przyjaciel czy wróg ksiażki, „Alma Mater" 2007, nr 90, s. 67-70.

${ }^{30}$ Kinga Mackiewicz, ,Tadeusz Eugeniusz Witkiewicz - Wielki Mistrz Rycerskiego Zakonu Bibliofilskiego", praca magisterska napisana pod kierunkiem prof. dr. hab. Janusza Kapuścika w Katedrze Bibliotekoznawstwa i Informacji Naukowo-Technicznej Uniwersytetu Łódzkiego.

${ }^{31}$ Paulina Nieradko, „Działalność bibliofilska i wystawiennicza Jerzego Dudy na tle ruchu bibliofilskiego w Krakowie", praca magisterska napisana pod kierunkiem prof. dr. hab. Zdzisława Pietrzyka obroniona w Instytucie Informacji Naukowej i Bibliotekoznawstwa Wydziału Zarządzania i Komunikacji Społecznej Uniwersytetu Jagiellońskiego w 2009 r. 
cerskiego Zakonu Bibliofilskiego z Kapitułą Orderu Białego Kruka w Krakowie w latach 1992-2013”32 Paulina Pietraszak napisała: „Zmyszenia Rycerskiego Zakonu Bibliofilskiego to przede wszystkim dzielenie się z innymi bibliofilami swoją pasją do ksiąg. Spotkania te wypełniają żywe dyskusje, rozmowy oraz wspominanie wydarzeń. Wszystkie wypełnia niesamowita atmosfera, której nie sposób odtworzyć w innym czasie i okolicznościach. Są to jedyne w swoim rodzaju towarzyskie spotkania z książką, pozwalające na spełnianie i rozwijanie swoich zainteresowań oraz na humorystyczne gawędy z ludźmi, którzy, każdy na swój sposób, kochają książki”.

Na początku 2017 r. Wielki Mistrz podjął decyzję o zorganizowaniu uroczystego ,zmyszenia" z okazji jubileuszu 25. rocznicy odrodzenia Zakonu w dniu 20 października $2017 \mathrm{r}$. $\mathrm{Z}$ wyborem miejsca nie było problemów, bowiem Pałac Larischa, w którym odbywało się poprzednie spotkanie, wyjątkowo przypadł do gustu komilitonom i zaproszonym gościom. Brat Pieczętarz prof. Piotr Dobosz wykorzystał wszelkie dostępne możliwości do uzyskania zgody od władz i przygotowania pomieszczeń na I piętrze do przyjęcia zakonnych dostojników oraz zaproszonych Gości. Kazimierz Wiśniak przygotował stosowny rysunek do zaproszenia, na którym Biały Kruk pokazany wśród książek sięga po lampkę szampana. Zaproszenie uzyskało nieco inny format, nową formę z wyraźnym, graficznym odniesieniem do jubileuszu. W jego treści znalazły się zapowiedzi „,przemówień, wspomnień, gratulacji, życzeń, a także owacji”. Gościem jubileuszowego „zmyszenia” był dr Tomasz Nastulczyk, zapowiedziany przez Brata Bibliografa prof. Wacława Waleckiego, z opowieścią o bibliofilskim wydaniu „Gawęd starego dziada”. W przechwałkach bibliofilskich znalazły się również tematy odnoszące się do: zabytkowych sztambuchów - przedstawiony przez Brata Arcykustosza prof. Zdzisława Pietrzyka oraz krasnoludków - rozwinięty w urokliwej książce świeżo wydanej i opracowanej graficznie przez Kazimierza Wiśniaka. Kluczowymi wydarzeniami ,zmyszenia” było: podsumowanie działalności Odrodzonego Zakonu w 25-leciu w wykonaniu Wielkiego Mistrza Zakonu oraz wystawa fotograficzna przygotowana i zaprezentowana przez zakonnego fotografa Władysława Malca. Wykorzystał on negatywy i zdjęcia przechowane na nośniku elektronicznym fotografii grupowych, których wykonywanie stało się od 1994 r. elementem rytuału po zakończeniu części merytorycznej każdego „zmyszenia”. Fotografie powiększone i oprawione stanowiły artystyczną oprawę wydarzenia. Ozdobą spotkania była także wystawa książek dla dzieci i młodzieży z ilustracjami wybitnych polskich ilustratorów, którzy otrzymali nagrody na Międzynarodowym Biennale Ilustracji organizowanym z Bratysławie od 1967 r. Książki pochodzą z kolekcji Wielkiego Mistrza.

Przy suto zastawionym stole rytualnym, na którym znalazły się i myszki bibliofilskie Wielkomistrzyni, i ciasto a la Veronka, a nawet niespodzianka w postaci innych smakołyków, zasiedli Zakonni Dostojnicy, Damy Książki, Dostojni Makulaturzyści i wybrańcy Ludu Bibliofilskiego oraz zaproszeni Goście w liczbie 36 osób. Z zainteresowaniem wysłuchano informacji o przeszłości Rycerskiego Zakonu Bibliofilskiego, jego narodzinach

${ }^{32}$ Paulina Pietraszak, „Działalność Odrodzonego Rycerskiego Zakonu Bibliofilskiego z Kapitułą Orderu Białego Kruka w Krakowie w latach 1992-2013”, praca magisterska napisana pod kierunkiem prof. dr. hab. Zdzisława Pietrzyka, obroniona w Instytucie Informacji Naukowej i Bibliotekoznawstwa Wydziału Zarządzania i Komunikacji Społecznej Uniwersytetu Jagiellońskiego w 2014 r. 
i pierwszych Dostojnikach, a także o działalności Odrodzonego Zakonu w ciągu 25 lat istnienia. Potem nastąpiło przekazywanie stosownych życzeń, adresów i wyrazów uznania składanych na ręce Wielkiego Mistrza. Od Towarzystwa Bibliofilów Polskich w Warszawie otrzymaliśmy adres z życzeniami „dalszej świetnej działalności. Niech Białokruczy Zakon przypomina pełną chwały bibliofilską przeszłość i wytycza książkolubom wciąż nowe czytelnicze szlaki”. Łódzkie Towarzystwo Przyjaciół Książki, ,grono Waszych admiratorów” wręczyło Zakonowi adres z gratulacjami i życzeniami dalszej owocnej działalności na rzecz książki i kultury słowa drukowanego, uzupełniając tekstem „Niech członkom Zakonu dopisuje krzepkie zdrowie i pogoda ducha, Niech Państwa zbiory bibliofilskie stale się wzbogacają i niech dostarczają wielu satysfakcji i radości”. Towarzystwo Przyjaciół Książki w Kaliszu przesłało życzenia, „by ruch miłośników książki, którego jakże ważną częścią jest Zakon, rozwijał się i trwał na przekór wszystkim przeciwnościom dotykającym przedmiot naszego umiłowania. Jesteśmy przekonani, że dopóki działać będzie niezrównany krakowski Zakon, piękna i wartościowa książka będzie obiektem szlachetnej bibliofilskiej zabawy".

W bibliofilskich przechwałkach, czyli merytorycznej części „zmyszenia”, znalazły się wystąpienia Gościa i Dostojników Zakonu na wcześniej podane tematy oraz zaprezentowano książkę, która wzbudziła szczególne zainteresowanie komilitonów. Książka autorstwa prof. Adama Wsiołkowskiego ${ }^{33}$, Dostojnej Makulatury, przyniesiona na jubileuszową biesiadę wprost z drukarni, jest autobiografią naszego konfratra zawierającą opowieść o drodze, jaką przebył od studenta Akademii Sztuk Pięknych w Krakowie do rektora tej uczelni. W bogato ilustrowanej książce są dwie strony, na których zarejestrowano uroczystość włączenia prof. Adama Wsiołkowskiego do Zakonu. Są na nich fotografie oraz reprodukcja patentu. Książka jest darem autora dla Zakonu i wzbogaci jego archiwum.

Dyskusjom i wspomnieniom na jubileuszowym spotkaniu nie było końca. Przypomnienie przez Tadeusza Serockiego, Dostojnej Makulatury, prac nad przygotowaniem reprintu jedynego polskiego egzemplarza Biblii Gutenberga znajdującego się w Pelplinie, który to reprint przyniesiony z Biblioteki Jagiellońskiej mógł każdy z uczestników dotknąć i obejrzeć, pobudzało do bibliofilskiej aktywności. Tym bardziej że Dostojna Makulatura Tadeusz ze swadą opowiadał o swojej edytorskiej współpracy z Biblioteką Jagiellońską i innymi bibliotekami, prezentując wybrane prace. Na zakończenie ,zmyszenia” Władysław Malec, zakonny fotograf, długo „ustawiał” pełnych energii i rozgadanych komilitonów do wykonania tradycyjnego zdjęcia. Udało się w końcu, o czym świadczy załączona fotografia.

Celem Rycerskiego Zakonu Bibliofilskiego, również w jego odrodzonej formie, jest podejmowanie i praktykowanie niekonwencjonalnych działań na rzecz wspólnoty ludzi miłujących książki oraz promowanie pewnych zachowań kulturowych odnoszących się do książki. Tradycja działalności i spotkań do dzisiaj jest żywa, pomimo utraty miejsca, zwanego „Gniazdem Białego Kruka”, w którym odbywały się „zmyszenia” i spotkania Braci Zakonnej. Zakon zachował swoją oryginalność, imponderabilia, wierność założeniom ideowym kolejnych Wielkich Mistrzów oraz dziedzictwo materialne, dzięki któremu istnieje możliwość udokumentowania trwałości i ciągłości działalności. Archiwum Zakonu jest bo-

${ }^{33}$ Adam W siołkowski, Moja Akademia, Kraków 2017. 
gate, zawiera cymelia, sprawozdania z wydarzeń i dokumenty świadczące o niezwykłym ksiąg miłowaniu ludzi nie przypadkiem zebranych w konfraterni, jedynej na świecie i to działającej od lat 87 w Krakowie, kolebce drukarstwa polskiego.

Rodzi się zatem nieśmiało wyrażona propozycja, zaprezentowana już przez niżej podpisanego w artykule zamieszczonym w pracy zbiorowej pod redakcją naukową Piotra Dobosza, Katarzyny Szepelak i Witolda Górnego ${ }^{34}$, aby Rycerski Zakon Bibliofilski z Kapitułą Orderu Białego Kruka w Krakowie mógł ubiegać się o status niematerialnego dziedzictwa kulturalnego miasta Krakowa. Czas do jubileuszu 90. Rocznicy powołania Zakonu wypełnimy wszelkimi dostępnymi działaniami w imię dobra „Pani Książki” i dyskusją o naszej nieśmiało wyrażonej propozycji w świetle Konwencji w sprawie ochrony kulturalnego dziedzictwa niematerialnego, przyjętej w 2003 r. przez UNESCO, ratyfikowanej przez Polskę w 2011 r., jak również konkretyzacji rozumienia pojęcia i definicji niematerialnego dziedzictwa kulturalnego.

Jerzy Duda

Pisali o Odrodzonym Zakonie:

(Bed) Tadeusz Zygmunt Bednarski, Odrodzenie Zakonu, „Dziennik Polski” z 3 marca 1993, s. 7.

Tadeusz Zygmunt Bednarski, Wśród bibliofilskiej braci, „Echo Krakowa” z 16 marca 1993, s. 6

(JD) Jerzy Duda, W Gnieździe Białego Kruka, „Czas Krakowski” z 13 kwietnia 1993, s. 13. Tadeusz Zygmunt Bednarski, W Gnieździe Białego Kruka, rozmowa z Wielkim Mistrzem Rycerskiego Zakonu Bibliofilskiego i Kapituły Orderu Białego Kruka Tadeuszem E. Witkiewiczem, „Przekrój” nr 30/2509, z 25 lipca 1993, s. 21, fot. 1.

(kas) Mieczysław Kasprzyk, ,Imieniny Ksiqżki”, „Echo Krakowa” z 8 marca 1994, s. 5. Ewa Owsiany, Rycerze Pani Ksiegi „Gazeta Krakowska” z 19-20 marca 1994, s. 4, fot. 1.

(kas) Mieczysław Kasprzyk, Biesiada Bibliofilska, „Echo Krakowa” z 27 października 1994, s. 28.

(Marabut Wytrwały) Bolesław Leonhard, Druga Kapituła Rycerskiego Zakonu Bibliofilskiego w Krakowie, „Skaut”, t. 32, nr 2 (420), z 31 października 1994, s. 18, fot. 1.

(J.R.) Jadwiga Rubiś, Księgoluby i kapitałki, „Dziennik Polski” z 11/12 lutego 1995, s. 21 , fot. 1 .

(kas) Mieczysław Kasprzyk, Biesiada Bibliofilska, „Echo Krakowa” z 9 lutego 1995, s. 7. Ewa Owsiany, Bractwo Białego Kruka, „Gazeta Krakowska” z 2-3 maja 1995, s. 11, fot. 1. Włodzimierz Jurasz, Dostojna Makulatura, „Czas Krakowski” z 16/17 września 1995, s. 11 , fot. 1 .

${ }^{34}$ Jerzy Duda, Tradycje Rycerskiego Zakonu Bibliofilskiego jako jeden z wyrazów niematerialnego dziedzictwa kulturowego Krakowa, [w:] Dziedzictwo, dobra kultury, zabytki, ochrona i opieka w prawie, pod red. Piotra Dobosza, Katarzyny Szepelak, Witolda Górnego, Publikacje Naukowe Sekcji Ochrony Dóbr Kultury Towarzystwa Biblioteki Słuchaczów Prawa Uniwersytetu Jagiellońskiego, Kraków 2015, s. 673-694. 
(WJ) Włodzimierz Jurasz, Nowy rycerz Zakonu, „Czas Krakowski” z 30 października 1995, s. 5 , fot. 1 .

Agnieszka Majewska, Zmyszone księgoluby, „Gazeta Wyborcza” Gazeta w Krakowie, z 10 maja 1995, s. 4, fot. 1 .

Anna Szulc, Rycerstwo zobowiazuje, „Gazeta Krakowska” Magazyn sobota-niedziela, z dnia 3-4 lutego 1996, s. 9, fot. 2.

(kas) Mieczysław Kasprzyk, Dziś w samo południe..., „Echo Krakowa” z 1-3 marca 1996, s. 3 , fot. 1 .

(RPM), Białe Kruki, jakich nigdzie nie ma, „Gazeta Krakowska” z 7 marca 1996, s. 14, fot. 1 .

Tomasz Zieja, Rycerze zaczytani, „Sycyna”, nr 34 z 17 marca 1996, s. 17, fot. 2.

Wystawa w Bibliotece Jagiellońskiej, Piękna Polaków Zabawa, Acta Universitatis Jagellonicae 1966, R. 13, nr 7 (200), s. 19, fot. 1.

Rita Pagacz-Moczarska, Kolektyw księgolubów, „Alma Mater” 1999, nr 13-14, s. 44-48, fot. 6 .

Ewa Owsiany, Rzeczpospolita bibliofilska, „Przegląd Polski” (Dodatek literacko-społeczny), Nowy Jork, z 7 stycznia 2000, fot. 1.

Tadeusz Zygmunt Bednarski, Żegnajac Tadeusza E. Witkiewicza, „Gazeta Wyborcza” Gazeta w Krakowie z 4 października 2001, s. 10.

Jerzy Duda, Strażnik Gniazda Białego Kruka, „Przekrój”, nr 41/2938, z 14 października 2001, s. 34, fot. 1.

Mieczysław Kasprzyk, W gnieździe Białego Kruka, „Echo Krakowa” Codzienny dodatek „Gazety Krakowskiej” z 13 marca 2002, s. III.

Bibliofilskie seminarium naukowe. Naukowe i techniczne problemy wielkich bibliotek polskich: Prof. dr hab. Stanisław Sierpowski Dyrektor Biblioteki PAN w Kórniku, dr Jerzy Duda Kanclerz Rycerskiego Zakonu Bibliofilskiego w Krakowie, Witryna Internetowa Stacji Naukowej Polskiej Akademii Nauk w Wiedniu pod redakcją prof. Mariana A. Hermana, Wiedeń, 2002, s. 40-42, fot. 3.

(Aleksandra Cieślik), Rycerze Białego Kruka, „Gość Niedzielny” Nasza Diecezja nr 20, z 19 maja 2002, s. 21-22, fot. 6.

(kas) Mieczysław Kasprzyk, Powstanie muzeum ksiażki?, „Gazeta Krakowska” z 23 kwietnia 2002, s. III.

Jerzy Duda, Rytirsky Bibliofilsky Rad s Kapitulou Radu Bile Vrany z Krakowa, „Zpravy” Spolku Ceskych Bibliofilu V Praze, 2002, nr 2, s. 28-31.

(kas) Mieczysław Kasprzyk, Msza święta bibliofilska, „Echo Krakowa” Codzienny dodatek „Gazety Krakowskiej” z 26 września 2002, s. IV.

Mieczysław Kasprzyk, Imieniny ksiażki, „Echo Krakowa” Codzienny dodatek „Gazety Krakowskiej” z 17 marca 2003, s. IV, fot. 1.

Mieczysław Kasprzyk, W Gnieździe Białego Kruka Imieniny ksiażki, „Echo Krakowa” Codzienny dodatek „Gazety Krakowskiej” z 9 marca 2004, s. 23.

(WJUR) Włodzimierz Jurasz, Biblioteki lecza dusze, „Gazeta Krakowska” z 2 stycznia 2005, s. 15.

(WJUR) Włodzimierz Jurasz, Dziś Międzynarodowy Dzień Ksiażki. Apel Bibliofilów, „Gazeta Krakowska” Magazyn na sobotę, z 23-24 kwietnia 2005, s. 20, fot. 1. 
Anna Petelenz, Dostojna Makulatura czeka na Białego Kruka, „Gazeta Krakowska” z 29 września 2006, s. 6, fot. 1.

(MAS) Lud bibliofilski wspominat swojego Wielkiego Mistrza. Będzie wystawa drukarstwa, „Gazeta Krakowska” z 23 października 2006, s. 9, fot. 1.

Jerzy Duda, Urszula Witkiewiczowa nie żyje, „Gazeta Krakowska” z 23 lutego 2007, s. 5.

Dorota Wierzbicka, Bibliofilstwo i internet. Internet - przyjaciel czy wróg ksiązki, „Alma Mater" 2007, nr 90, s. 67-70.

Wacław Walecki, Kak ja stat wysokocztimoj makulaturoj (Wospominaniai smesznyje i sierioznyje), „Pro Knigi” (żurnal bibliofiła) 2007, nr 3, s. 139-144, fot. 8.

Jerzy Duda, Bibliofilstwo w kręgu Witkiewiczów, [w:] Pamiętnik X Ogólnopolskiego Zjazdu Bibliofilów w Kaliszu 14-16 września 2007 r., oprac. Ewa Andrysiak, Krzysztof Walczak, Towarzystwo Przyjaciół Książki w Kaliszu, Kalisz 2008, s. 57-65, fot. 1.

Jerzy Duda, Bibliofilstwo w kręu Witkiewiczów, „Alma Mater” 2008, nr 101, s. 48-53, fot. 10 .

Włodzimierz Jurasz, Smutne Imieniny ksiażki, „Dziennik Polski” Kronika Krakowska z 11 marca 2008, s. 2, fot. 1.

Włodzimierz Jurasz, Testament Pani Urszuli, „Dziennik Polski” Kronika Krakowska z 14 marca 2008, s. 1, fot. 1 .

(WJUR) Włodzimierz Jurasz, A mole się cieszq, „Dziennik Polski” z 3 września 2008, s. 3.

(WJUR) Włodzimierz Jurasz, Tam, gdzie siadywał Witkiewicz, „Dziennik Polski” Kronika Krakowska z 2 czerwca 2008, s. 2, fot. 1.

Jerzy Duda, Bibliofilu Riteriu Ordinas Krokuvoje, ,tarp KNYGU” 2011, nr 4 (627), s. 16-17, fot. 2 .

Małgorzata Skowrońska, Zmyszenie z Dostojnym Woluminem, „Gazeta Wyborcza”, Gazeta Kraków, Tematy na piątek, z 26 października 2012, s. 8-9, fot. 2.

Maria Kocójowa, Dama Ksiażki ze złoceniami Alina Kalczyńska-Scheiwiller, „Akapit” 2014, t. 9, s. 60-64, fot. 9.

Milica Majericova-Molitoris, Prve polsko-slovenske stretnutie ludu bibliofilskeho v Novej Belej, „Żivot” 2015, nr 11 (689), s. 33, fot. 3.

Rita Pagacz-Moczarska, Jerzy Duda, Archiekslibrisofil (wspomnienia o Andrzeju Znamirowskim 1944-2015), „Alma Mater” 2016, nr 182-183, s. 54-55, fot. 6.

Maria Mazurek, Papier przetrwa, bo najszybciej starzeje się... nowoczesność, „Gazeta Krakowska” Magazyn z 20 października 2017, s. 22, fot. 1. 